\title{
Analysis of Nila Fish Supply Chain in Toba Samosir Regency
}

\section{Julia Marisa}

Department of Agroecotechnology, Faculty of Sains and Technology, Pembangunan Panca Budi University, Medan 20122, Indonesia

Email address : juliamarisa@pancabudi.ac.id

\begin{abstract}
Proper supply chain management in tilapia commodities in Toba Samosir Regency is needed to add value, maintain stock and quality, and can be easily reached by consumers/ communities. This study aims to determine the production process, analyze the actors involved, and analyze product flow, money flow and information flow in the tilapia fish supply chain in Toba Samosir Regency. This research is a qualitative descriptive study. Data analysis method is carried out in several steps: 1) Data Collection, 2) Data Reduction, 3) Data Display, 4) Drawing Conclusion and Verification. The results of this study are 1) Tilapia fish production process in Toba Samosir Regency is carried out with two systems, namely the first fish cultivation is done starting from the nursery and the second is cultivation for enlargement. 2) The actors involved in the supply chain system for the freshwater fish industry in Toba Samosir Regency are Fish Cultivators, Collectors, Diluents, Fish Processing Industries, Consumers. 3) There are product flow, money flow and information flow in the supply chain of the freshwater fishing industry in Toba Samosir Regency. Product flow flows from upstream to downstream, financial flow flows from downstream to upstream and information flows flow in both directions.
\end{abstract}

Key words: Industry, Supply Chain, Tilapia, Toba Samosir Regency.

Citation to this paper should be made as follows :

Marisa, J. 2019. Analysis of nila fish supply chain in Toba Samosir Regency. Agritropica: Journal of Agricultural Science. 2 (1): 26-32. DOI: https://doi.org/10.31186/J.Agritropica.2.1.26-32

\section{INTRODUCTION}

Toba Samosir Regency is very potential for the development of captured fisheries and aquaculture that can improve the economy of the region. This economic improvement can be done by developing tourism potential, fisheries, and livestock. In this way, the unemployment rate in Toba Samosir will decrease and economic growth and development will grow rapidly. The success of development in Toba Samosir Regency demands cooperation and support from various parties and the role of each sector. One sector that is expected to support the objectives of economic development in Toba Samosir (Tobasa) Regency is the fisheries sector.
Tobasa Regency is one of the regions that have the largest tilapia production. Most of the main livelihoods of residents in the area are tilapia farmers with floating net cages. The prospect of developing the production of aquaculture commodities in this area is quite good. Supported by the location factor of the area which is located on the outskirts of Lake Toba, making the residents use it to cultivate tilapia. Supply chain management is a concept of the right approach to address the problem of fulfilling consumer demand. The time to deliver products to end consumers is demanded as efficiently as possible while maintaining product quality (Tompodung, et al., 2016). 
Supply chain management in fresh tilapia is very necessary, because these commodities have economic value, high demand, and high benefits for farmers, fish processing industries and the community. Proper supply chain management in tilapia commodities in Tobasa Regency is needed to add value, maintain stock and quality, and can be easily reached by consumers/ communities. Production of fishery products is strongly influenced by the demand for a commodity.

In the supply chain, there are regulatory systems that are related to product flow, information flow, and financial flow. This arrangement is important to know about the number of links involved in the fish commodity supply chain and the characteristics of products that are easily damaged compared to the results of other commodities. Tilapia supply chains need to pay attention to several aspects that can affect the smooth distribution process to the end consumers. In addition to meeting consumer demand, the form of regulation in the fish supply chain also aims to benefit each of the links involved. So we need an approach to the supply chain system in the form of an approach to find out the product flow, financial flow, information flow because it will influence the decision making in each of the existing links. Appropriate decision making will be useful in maintaining the supply and quality of Tilapia commodities.

\section{Research Purposes}

The purposes of this research were:

1. To know the production processes in the supply chain of tilapia in the District Tobasa

2. To analyze the actors involved in the supply chain system of tilapia in the District Tobasa.
3. To analyze product flow, cash flow and information flow in the supply chain of tilapia in the District Tobasa.

\section{Research Urgency}

The virtues of this research were:

1. To provide solutions in fish supply chains that can affect the smooth distribution process to the end consumers.

2. To provide a solution to the problem of tilapia business in meeting consumer demand through several approaches that are useful to determine product flow, money flow, and information flow, because it will influence the decision making in each of the existing links. Appropriate decision making will be useful in maintaining the supply and quality of Tilapia commodities.

\section{RESEARCH METHODS}

This research was carried out in the District of Toba Samosir, North Sumatra. The reason for choosing the location is because the Toba Samosir Regency is the largest tilapia production area in North Sumatra and many people depend on Tilapia cultivation. Data analysis used is qualitative and quantitative data analysis. Qualitative analysis is carried out to see the identity of processing farmers including name, age, gender, latest education, basic livelihoods and business experience, a form of business. While quantitative analysis is carried out to see the supply chain, namely: (a) Flow of Goods, (b) Flow of Money and (c) Information Flow.

\section{Supply Chain Concept}

According to Chopra and Meindl (2007) in Rouli (2008), the supply chain 
has a dynamic nature but involves three streams of information, products, and money. The main objective of each supply chain is to meet consumer needs and generate profits. In general, activities in the supply chain of manufacturing companies consist of several individual companies involved in processing a product and channeling it to end consumers - component and raw material producers, product assemblers, wholesalers, retailers, and transportation companies are members of the supply chain, so each company will become part of a supply chain (Ganika, 2016).

\section{RESULTS AND DISCUSSION}

\section{Analysis of Freshwater Fish Supply Chain}

Baatz (1995) states that conceptually the supply chain is the entire process from raw material to be produced to become a product that has an end of life. Golicic, et al (2002) stated that the supply chain must be able to explain the fundamental relationship between members in an organization from simple transactions to very complex transactions. According to Vorst (2006) to analyze a complex supply chain requires "language" that can describe supply chains, parties involved, processes, products, resources, management, relationships between attributes and other undefined things.

\section{Identification of Fish Supply Chain Actors}

The actors involved in the supply chain system of freshwater fish in Tobasa Regency are:

1. Fish Farmers

2. Wholesalers

3. Retail Traders

4. Fish processing industry

5. Consumers

\section{Mechanism of Product Flow, Financial Flow and Information Flow on Freshwater Fish Supply Chain}

Distribution channels in the supply chain of Tilapia in Tobasa Regency describe product flow, financial flow, and information flow that occurs between chain members. In this Tilapia supply chain, there are three channels in the supply chain which can be seen in Figure 1.

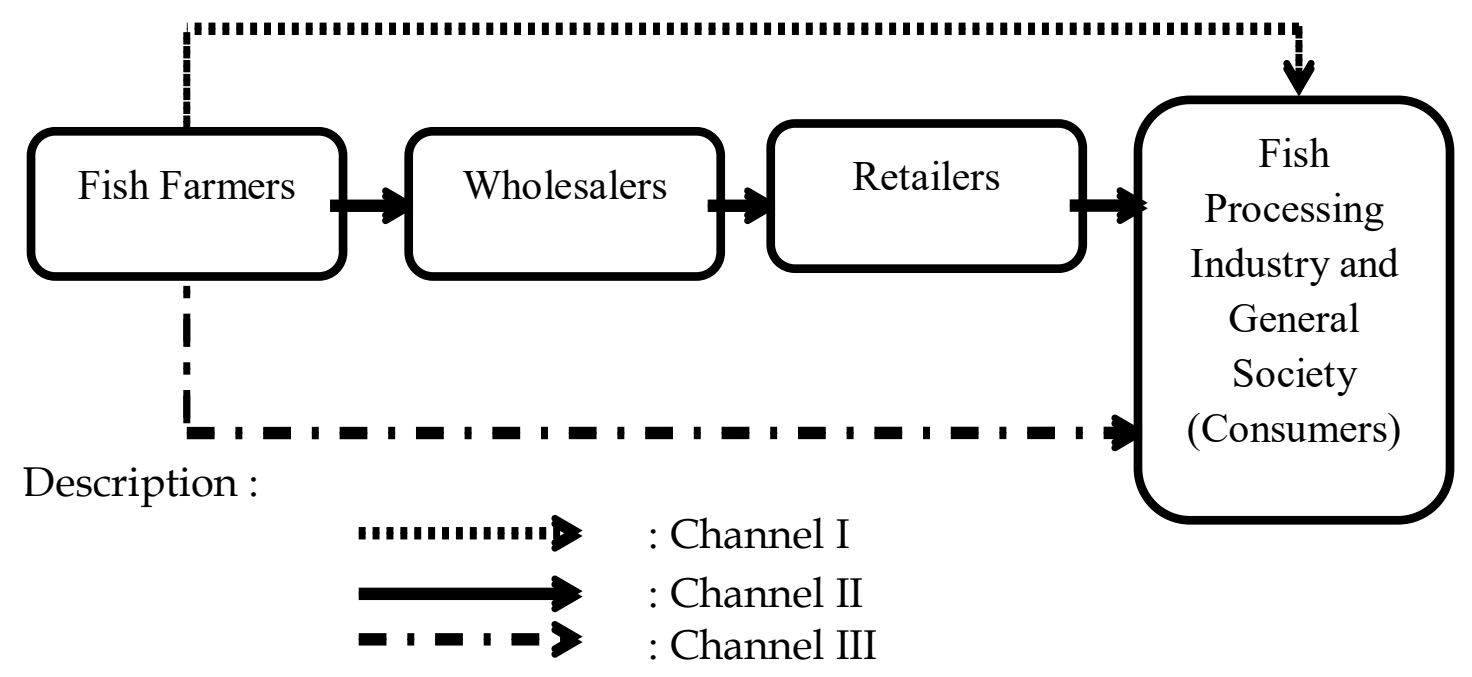

Figure. 1. Distribution Patterns in the Tilapia Fish Supply Chain in Tobasa Regency 


\section{Channel I: Fish Farmer - Fish Processing Industry}

The first supply chain channel in the marketing of Freshwater Fish commodities in Tobasa Regency consists of fish cultivators and fish processing industries. The channel design used in the first supply chain channel is a zero level channel, which is where the zero level channel producer, in this case, the fish cultivator directly sells the Mujair fish commodity to the entrepreneur of the fish processing industry. There is a product flow, information flow, and financial flows that occur in the supply chain channel I. The form of flow that occurs in the supply chain channel I can be seen in the following figure.

\section{Product Flow}

Product flow that occurs in the channel I is the sale of products in the form of fresh fish which are carried out by fish farmers to industrial owners. In distributing Fish products there is no fixed amount that can be obtained by industrial owners. This is because the amount of fish produced/harvested cannot be ascertained by farmers because the harvest time takes up to 4 months and the risk that can occur at any time at the time of production activities that cause production results are sometimes erratic. To fulfill the product needs of the fish processing industry, the entrepreneur does not work with some fish farmers.

\section{Financial Flow}

The financial flow that occurs in channel I, namely from fish processing industry entrepreneurs to farmers who conduct fish production activities. The mechanism of financial flow is emphasized on the payment transaction system and in channel I the payment transaction system is carried out in cash. The payment transaction system occurs when the fish is ready to be transported by the processed industry owner.

\section{Information Flow}

Information flow that occurs in the channel I include information on quantity/amount of supply requests, price information, and time information. The fish processing industry informs the number of requests to fish cultivators through telecommunication media (telephone), then the fish cultivator will inform fish stocks that can meet the demand. Price information is agreed between fish farmers and owners of the processing industry by looking at market prices and the number of requests and supplies from fish farmers. Information on the time to purchase Fish is determined and delivered by the farmer to the restaurant owner, this is done so that when the fish purchase activity is obtained with good quality and condition.

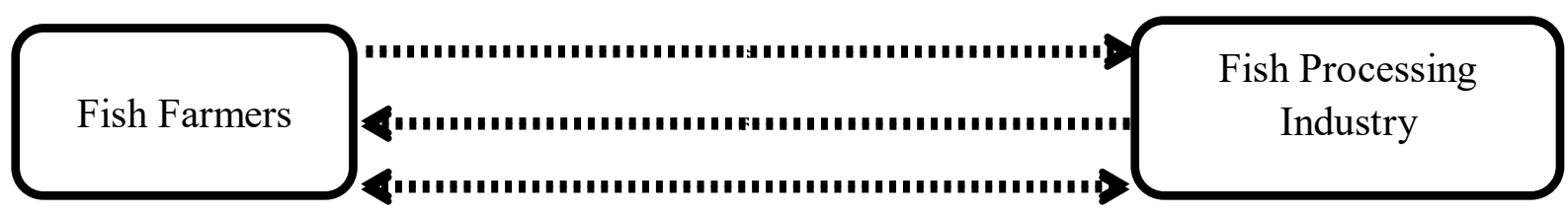

Description:

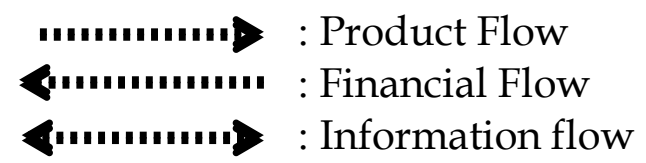

Figure 2. Fish Farmer - Fish Processing Industry. 
Channel II: Fish Farmers - Wholesalers Retailers - Consumers

The second supply chain channel consists of Fish Farmers, Wholesalers, Retailers, and Consumers. The channel design used in this supply chain channel is a second level channel (two level channel), where this second level channel is a large trader selling to retailers which are then sold to consumers. In this channel wholesalers sell it to retailers, then distribute it to retailers such as supermarkets and also to traders in traditional markets in Tobasa Regency, then sell to the general public. There are product flows, financial flows and financial flows that occur in this supply chain II. The form of flow that occurs in supply chain II can be seen in the following figure.

\section{Product Flow}

Product flow that occurs in channel I is from fish farmers, then the fish is sold to large traders who live in the surrounding area, who come directly to the location of fish farmers. The amount of fish that must be purchased by a large trader is a minimum of 100 kilograms of fish meat, equivalent to 300-400. Furthermore, large traders distribute Fish in mini-supermarkets, also to traders in traditional markets, then the Fish is sold to the general public with a number of kilograms or a fish.

Fish Farmers

\section{Financial Flow}

Financial flows that occur in channel II, namely from wholesalers to fish farmers, retail traders to wholesalers and consumers to retail traders. The mechanism of financial flow is emphasized on the payment transaction system and on this channel II the payment transaction system is carried out in cash. The system of payment transactions between large traders and fish cultivators occurs when fish are ready to be transported by large traders, then between retail traders and wholesalers occurs when fish have been sold to consumers (the general public).

\section{Information Flow}

Information flow that occurs in channel II includes information on quantity/amount of demand-inventory and price information and time information. Large traders will check the availability of fish stocks through telecommunication media (telephone), then the fish cultivator will inform the number of stocks of fish stocks they have. Price information is agreed between farmers and wholesalers by looking at market prices and the number of requests from wholesalers as well as supplies from farmers.

Description :

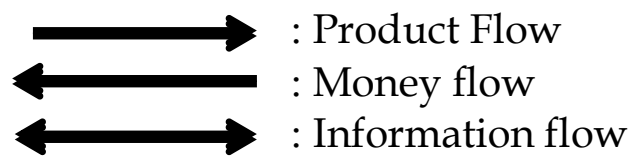

Figure 3. Fish Farmers - Wholesalers - Retailers - Consumers 
Information on the time to purchase fish is determined and delivered by fish cultivators to large traders, this is done so that when fish purchase activities are obtained with good conditions and quality.

\section{Channel III: Fish Farmers - Consumers.}

The third supply chain channel in the marketing of commodity Tilapia Tobasa Regency consists of Fish Cultivators and the General Community (Consumers). The channel design used in this third supply chain channel is a zero level channel, which is where the zero level channel producers in this case fish farmers directly sell fish commodities to consumers. Channel III is rarely used, it usually occurs only at certain times and conditions such as when approaching the Christmas and New Year holidays, fish cultivators open a place to sell fish in their yard. There are a product flow, information flow and financial flow that occurs in this supply chain III. Clearly, the flow that occurs in supply chain III can be seen in the following figure.

\section{Product Flow}

Product flow that occurs in channel III is from fish farmers who sell their products directly to consumers. Fish farmers distribute products directly without minimum purchase in other words fish can be purchased with a fish or kilogram of fish meat or with a retail system.

\section{Financial Flow}

Financial flow on channel III is from consumers directly to fish cultivators who conduct production activities of freshwater fish farming. The mechanism of financial flow is emphasized on the payment transaction system and on channel III this payment transaction system is carried out in cash. Payment transaction systems occur when fish are ready to be brought by consumers.

\section{Information Flow}

Information flow on channel III includes information on quantity/quantity of requests and price information. Consumers inform the number of requests to fish farmers directly at the place of buying and selling activities. Price information is agreed between fish farmers and consumers by looking at market prices and the number of requests from consumers.

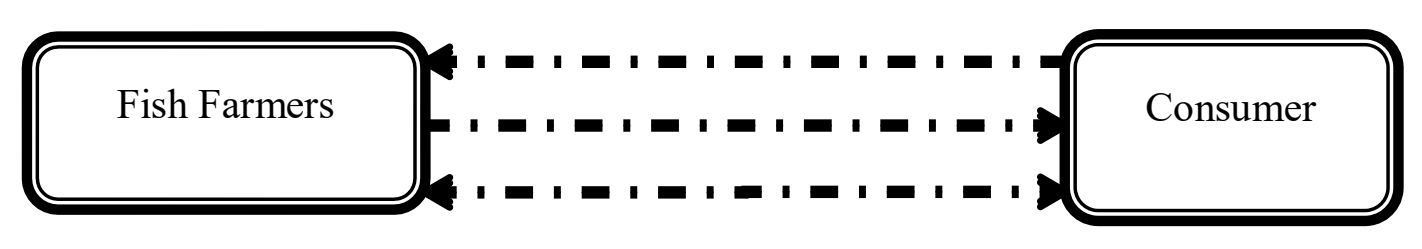

Description :

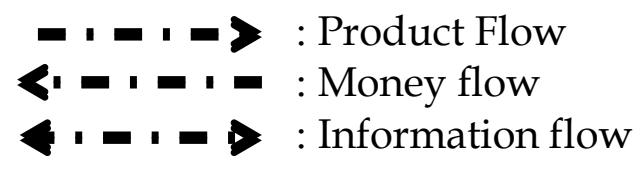

Figure 4. Fish Farmers - Consumers 


\section{CONCLUSIONS}

The process of tilapia production in Tobasa Regency is carried out in 2 systems, namely fish cultivation, starting from the nursery and the second is cultivation for fish rearing. The actors involved in the tilapia fish supply chain system in Tobasa Regency are: Fish Cultivators, Collecting Traders, Retailers, Fish Processing Industries, Consumers. There is product flow, money flow and information flow in the tilapia fish supply chain in Tobasa Regency. Product flow flows from upstream to downstream, financial flow flows from downstream to upstream and information flows flow in both directions. It is recommended to conduct further research on product, financial and information flow in the tilapia business in Toba Samosir Regency.

\section{REFERENCES}

Baatz, E.B., 1995. CIO 100 \} Best practices: the chain gang. CIO 8 (19), 46\}52.

Chopra, S. and Meindl, P. 2007. Supply chain management. Strategy, planning \& operation. Das summa summarum des management. Gabler. 265-275.
Ganika, G. Keterkaitan antara orientasi rantai pasok, berbagi informasi dan kepuasan inter-relasi antar perusahaan. SEGMEN-Jurnal Manajemen dan Bisnis 12.1 (2016).

Golicic, S. L., D. F. Davis, T. M. McCarthy, \& J. T. Mentzer. 2002. The impact of e-commerce on supply chain relationships. International

Journal of Physical Distribution \& Logistics Management, 32(10), 851-871.

Rouli, J. (2008). Evaluasi suply chain management dengan pendekatan scor model versi 8.0 (Doctoral dissertation, Universitas Indonesia. Fakultas Ekonomi).

Tompodung, E., Worang, F. G., \& Roring, F. (2016). Analisis rantai pasok (supply chain) ikan mujair di Kecamatan Eris Kabupaten Minahasa. Jurnal EMBA: Jurnal Riset Ekonomi, Manajemen, Bisnis dan Akuntansi, 4(3): 279-290

Van Der Vorst, J. G. (2006). Performance measurement in agri-food supplychain networks. Quantifying the agri-food supply chain, 15-26. 